\title{
Therapeutic effect of lycopene-rich tomato juice on cardiac disorder in rats fed on fried food in oxidized frying oil
}

\author{
Hassan H. A. and Edrees G. M. \\ Zoology Department, Faculty of Science, Mansoura University, Mansoura, Egypt.
}

\begin{abstract}
Therapeutic effect of lycopene-rich tomato juice against evoked cardiac disorders in rats fed on fried potato in oxidized frying cotton seed oil $(20 \% \mathrm{w} / \mathrm{w})$ for 4 -weeks was studied using lycopene at a daily dose of $1 \mathrm{mg} / \mathrm{Kg}$ body weight.

Total lipids, total cholesterol, triglycerides, phospholipids, low-density lipoprotein cholesterol (LDL-c) and high-density lipoprotein cholesterol (HDL-c) were estimated in different animal groups. Lactic dehydrogenase (LDH), creatine kinase (CK), aspartate aminotransferase (AST) and alanine aminotransferase (ALT) as well as serum calcium, potassium and magnesium were determined

The obtained results revealed that, feeding on fried potato in deep oxidized frying oil induced a notable increase in lipid profils and LDL-c associated with a marked elevation in specific heart enzymes, LDL, CK, ALT and AST activities. These biochemical alterations ameliorated when lycopene was administered to rats fed fried potato in oxidized frying oil.
\end{abstract}

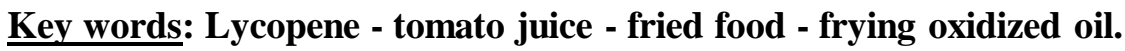

\section{Introduction}

Vegetables and fruit are rich sources of a variety of nutrients, including vitamins, trace minerals, and dietary fiber, and many other classes of biologically active phytochemical compounds (Lampe, 1999).

Epidemiologic data support the association between high intake of vegetables and fruits and low risk of different chronic diseases as several common cancers (Steinmetz and Potter, 1996) and cardiovascular disease ( Banerjee and Maulik 2002 and Seifried et al., 2003).

Lycopene is considered as one of the phytochemical, synthesized by plants and microorganisms but not by animals. Human can not produce lycopene, so, they must take it in their food (Bramley, 2000).

Lycopene is a hydrocarbon carotenoid found in tomatoes, tomato products and in other fruits (Clinton, 1998). Lycopene is associated with the red color in tomatoes. Concentrated cooked sources of tomatoes, such as tomato sauce, are associated with greater health benefits. Lycopene can be absorbed more efficiently by the body after it has been processed into juice, sauce, paste or ketchup (Giovannucci, 1999). Heating and adding a small amount of fat makes the lycopene more easily absorbed by the body (Arab and Steck, 2000).

Diets high in fat, saturated fat and cholesterol, in addition to physical inactivity, still plays a key role in heart disease risk by increasing blood lipids (Ernst and Schaefer, 2002).

During deep-fat frying, when the fat is used repeatedly, oxidative and thermal effects result in the formation of many volatile and nonvolatile products, some of which are potentially toxic and accumulate in our dietary frying food (Battino et al., 2002).

Fat frying is a popular food preperation method, but several components like antioxidant vitamins could be lost due to oxidation and some others with toxic effects could appear. Many reactive 
electrophilic chemicals (e.g. acrylamide and hydrazine) are most probably formed during heating of starch-rich foods to high temperatures and these could individually or cumulatively contribute to human cancer or other diseases (He et al., 2004).

The process of hydrogenation increases the saturated fat content. Unfortunately, this process produces transfatty acids, which plays a major role in disease. This of course, increases the risk of atherosclerosis, diabetes, obesity, heart disease and a weakened immune system (Otero, 1997).

Therefore, a good opportunity has been taken to investigate the possible curative or ameliorative effects of lycopene-rich tomato juice against induced cardiac disturbances in rats fed on fried potato in oxidized frying oil.

\section{Materials And Methods}

\section{Experimental animals:}

Adult male rats (Rattus norvegicus) weighing 120-150 gm were used in this study. They were placed in separate cages and allowed food and water ad libitum. They were kept under suitable airflow and temperature during the whole period of experimentation.

\section{Preparation of fried potato, oxidized frying oil and tomato juice:}

Cotton seed oil and potato purchased from a local supermarket were subjected to the following frying process:- Oil was poured into a cast iron wok and heated on a gas stove which was adjusted to maintain the oil temperature at $205 \pm 5{ }^{0} \mathrm{C}$. Potatos were peeled and cut into sticks then fried in the oil. Every $30 \mathrm{~min}$, a batch of potato sticks was fried for $5 \mathrm{~min}$. The potato frying process was performed for $4 \mathrm{hrs} /$ day and was repeated for 7 successive days (Liu and Lee, 1998 ). The first fried potato (after 3 min from frying process) and the last fried potato (after $28 \mathrm{hrs}$ from frying oil process) were used only in the experimental study to evaluate the effect of fried food in deep oxidized oil.
Concerning tomato juice preperation, fresh tomatoes washed and good homogenized by mechanical process then slightly heated with little amount of olive oil to facilitate lycopene absorbtion by the body (Arab and Steck, 2000).

\section{Experimental design:}

Rats were divided into five main groups, each consists of 6 rats. Groups were treated as follows:

Group I: Control untreated group: normal control rats were maintained on normal diet and provided with tap water.

Group II: Lycopene-rich tomato juice treated group: Rats received orally tomato juice at a daily dose of $8.25 \mathrm{ml} / \mathrm{Kg}$ body weight which equal daily lycopene dose of $1 \mathrm{mg} / \mathrm{Kg}$ body weight (Micozzi et al., 1992 and Liu et al., 2003) for 4- weeks. (paetau et al., 1999)

Group III: First fried potato - fed rats treated group: Animals received first fried potato in deep oxidized frying oil (after 3 min only from frying process of oil) (20\% $\mathrm{w} / \mathrm{w}$ in diet) for 8-weeks.

Group IV: Last fried potato- fed rats treated group: Rats received $20 \%$ last fried potato in deep oxidized frying oil (after 28 hour from frying process of oil) for 8weeks.

Group V : Last fried potato-fed rats and lycopene treated group: Rats received last fried potato in deep oxidized frying oil (after 28 hour from frying process of oil) $(20 \% \mathrm{w} / \mathrm{w}$ in diet) for 4-weeks and simultaneously adminestered orally with lycopene as tomato juice at the same mentioned dose $(1 \mathrm{mg} / \mathrm{Kg}$ B wt) besides the same diet of deep fried potato for another 4- weeks.

Rats of different groups were weighed weekly to calculate the body weight change.

\section{Blood and Tissue sampling:}

At the end of the period of treatment fasted overnight animals were sacrified by cervical dislocation and blood was collected in clean centrifuge tubes. Serum was seperated from coagulated blood by 
centerifugation at $3000 \mathrm{~g}$ for $20 \mathrm{~min}$. Serum were quickly frozen at -20 till time analysis. Liver and heart were dissected as rapidly as possible, weighed, homogenized in ice cold saline solution and were also frozen at $20{ }^{\circ} \mathrm{C}$ for subsequent analysis..

\section{Biochemical analysis:}

Total lipids, total cholesterol, triglycerides, LDL-c and HDL-c were determined by using a commercially available reagent Kits obtained from Randox Lab Ltd, U.K.. Phospholipid was assayed according to the method of Baginiski et al. (1972). The activity of the following enzymes LDH, CK, AST and ALT were determined using reagent Kits supplied by Bio-Merieux Laboratory Reagents and Products, France. Serum Calcium, Potassium and Magnesium were estimated by an atomic absorption spectrophotemeter following the method of Zettner and Seligson (1964).

\section{Statistical analysis:}

Statistical analysis of the present data and student's t-test were carried out as described by Sokal and Rahif (1981).

\section{Results}

The obtained results of the present work are represented in Tables 1, 2, 3, 4 and 5 respectively.

Table (1) showed that, the percentage of body weight gain in group (IV) increased after the experimental period when comparing with group (111), meanwhile, rats supplemented with lycopene, group (V) tend to reach control level.
Table (2) demonestrated the serum and liver concentrations of lipids profils as well as serum lipoprotein fractions, as LDL-cholesterol and HDL-cholesterol levels for the control and treated rats. The results showed that all classes of serum and liver lipids as well as serum LDLcholesterol were significantly increased in deep fried potato in oxidized frying oil fed rats, while serum HDL-cholesterol was significantlly decreased. On the other hand the lycopene rich tomato juice ameleorate lipid fractions and lipoproteins. This effect is manifested by the significant decrease in lipid fractions, LDL-cholesterol and a marked elevation in a HDL-cholesterol.

The levels of LDH, CK, AST and ALT in seum, liver and heart for control and treated rats were cited in Table (3). Rats fed on deep fried potato in oxidized frying oil had more activity of the LDH, CK,AST and ALT in serum, liver and heart as compared with rats fed on fried potato in normal oil (Group III). However, administration of lycopene rich tomato juice to rats that received fried potato in oxidized frying oil, showed a significant decrease in the activity of all the above mentioned enzymes when compared to group (IV).

The data for serum $\mathrm{Ca}, \mathrm{K}$ and $\mathrm{Mg}$ concentrations in of the control and treated rats were summarized in Table (4). Dietary deep fried potato in oxidized frying oil decreased the serum $\mathrm{K}$ and $\mathrm{Mg}$ concentrations. However, serum $\mathrm{Ca}$ level was increased. Moreover, an undesirable rise in serum calcium / magnesium ratio was recorded in deep fried potato fed rats. When concomitant administration of lycopene to rat fed deep fried potato in frying oil, the ratio was decreased compared to rats fed on fried potato in normal oil (group III). 
Table (1): Mean percentage of body weight gain during 8 weeks in control and treated animal groups.

\begin{tabular}{|c|c|c|c|c|c|}
\hline $\begin{array}{c}\text { Groups } \rightarrow \\
\text { Parameters } \downarrow\end{array}$ & $\begin{array}{c}\text { Group } \\
\text { I }\end{array}$ & $\begin{array}{c}\text { Group } \\
\text { II }\end{array}$ & $\begin{array}{c}\text { Group } \\
\text { III }\end{array}$ & $\begin{array}{l}\text { Group } \\
\text { IV }\end{array}$ & $\begin{array}{c}\text { Group } \\
\mathrm{V}\end{array}$ \\
\hline Before examination & $100 \%$ & $100 \%$ & $100 \%$ & $100 \%$ & $100 \%$ \\
\hline $1^{\text {st }}$ Week & 106 & 108 & 105 & 105 & 105 \\
\hline $2^{\text {nd }}$ Week & 110 & 115 & 110 & 110 & 110 \\
\hline $3^{\text {rd }}$ Week & 115 & 123 & 115 & 117 & 117 \\
\hline $4^{\text {th }}$ Week & 122 & 130 & 124 & 125 & 125 \\
\hline $5^{\text {th }}$ Week & 127 & 134.5 & 131 & 130.3 & 129 \\
\hline $6^{\text {Th }}$ Week & 135 & 140 & 147 & 137 & 135 \\
\hline $7^{\text {th }}$ Week & 140 & 146 & 145 & 144 & 141 \\
\hline $\begin{array}{c}8^{\text {th }} \text { Week } \\
\% \text { of change }\end{array}$ & 147 & $\begin{array}{c}153 \\
+0.041^{\circ}\end{array}$ & $\begin{array}{c}148 \\
+0.007^{\circ}\end{array}$ & $\begin{array}{c}153 \\
+0.034 *\end{array}$ & $\begin{array}{c}146 \\
-0.046^{\circ}\end{array}$ \\
\hline
\end{tabular}

$\bullet \%$ of change compared to control (Group I).

* \% of change compared to group III.

$\circ \%$ of change compared togroup IV. 
Table (2): Changes in total lipids, total cholesterol, triglycerides, phospholipids in serum and liver as well as LDL-cholesterol and HDL-cholesterol levels in control and treated groups.

\begin{tabular}{|c|c|c|c|c|c|c|}
\hline & $\begin{array}{c}\text { Groups } \rightarrow \\
\text { Parameters } \downarrow\end{array}$ & $\begin{array}{l}\text { Group } \\
\text { I }\end{array}$ & $\begin{array}{l}\text { Group } \\
\text { II }\end{array}$ & $\begin{array}{l}\text { Group } \\
\text { III }\end{array}$ & $\begin{array}{l}\text { Group } \\
\text { IV }\end{array}$ & $\begin{array}{c}\text { Group } \\
\mathrm{V}\end{array}$ \\
\hline \multirow{6}{*}{$\underset{\Xi}{\Xi}$} & Total lipids (mg/dl) & $\begin{array}{l}738.11 \\
\pm 3.52 \\
\end{array}$ & $\begin{array}{l}699.11 \\
\pm 2.31^{\circ}\end{array}$ & $\begin{array}{l}812.10 \\
\pm 3.24^{\circ}\end{array}$ & $\begin{array}{l}998.25 \\
\pm 1.25^{*}\end{array}$ & $\begin{array}{l}803.41 \\
\pm 3.25^{\circ}\end{array}$ \\
\hline & Total cholesterol (mg/dl) & $\begin{array}{l}129.91 \\
\pm 3.25 \\
\end{array}$ & $\begin{array}{l}102.56 \\
\pm 2.35^{\circ} \\
\end{array}$ & $\begin{array}{l}134.11 \\
\pm 1.24 \\
\end{array}$ & $\begin{array}{r}187.22 \\
\pm 3.21 * \\
\end{array}$ & $\begin{array}{r}167.52 \\
\pm 2.35^{\circ} \\
\end{array}$ \\
\hline & Triglycerides (mg/dl) & $\begin{array}{l}101.11 \\
\pm 0.21 \\
\end{array}$ & $\begin{array}{l}100.21 \\
\pm 0.45 \\
\end{array}$ & $\begin{array}{l}112.31 \\
\pm 0.32^{\circ} \\
\end{array}$ & $\begin{array}{r}134.21 \\
\pm 0.36^{*} \\
\end{array}$ & $\begin{array}{r}122.32 \\
\pm 0.52^{\circ} \\
\end{array}$ \\
\hline & $\begin{array}{c}\text { Phospholipid } \\
(\mu \mathrm{mol} / \mathrm{min} / 100 \mathrm{ml})\end{array}$ & $\begin{array}{r}8.41 \\
\pm 1.20 \\
\end{array}$ & $\begin{array}{r}7.94 \\
\pm 2.01 \\
\end{array}$ & $\begin{array}{c}9.11 \\
\pm 2.05 \\
\end{array}$ & $\begin{array}{r}14.52 \\
\pm 1.21 * \\
\end{array}$ & $\begin{array}{r}10.12 \\
\pm 2.45 \\
\end{array}$ \\
\hline & HDL-cholesterol (mg/dl) & $\begin{array}{r}44.37 \\
\pm 2.21\end{array}$ & $\begin{array}{l}49.21 \\
\pm 3.25\end{array}$ & $\begin{array}{l}41.11 \\
\pm 2.35\end{array}$ & $\begin{array}{c}30.21 \\
\pm 3.50 *\end{array}$ & $\begin{array}{l}49.21 \\
\pm 2.58^{\circ}\end{array}$ \\
\hline & LDL-cholesterol (mg/dl) & $\begin{array}{r}65.32 \\
\pm 2.01\end{array}$ & $\begin{array}{r}32.51 \\
\pm 2.41^{\circ}\end{array}$ & $\begin{array}{r}70.54 \\
\pm 1.03^{\circ}\end{array}$ & $\begin{array}{r}130.17 \\
\pm 2.35 *\end{array}$ & $\begin{array}{r}93.85 \\
\pm 2.89^{\circ}\end{array}$ \\
\hline \multirow{4}{*}{$\stackrel{\grave{D}}{\Xi}$} & Total lipids (mg/ g wet tissue) & $\begin{array}{r}32.3 \\
\pm 4.52 \\
\end{array}$ & $\begin{array}{l}34.11 \\
\pm 6.24 \\
\end{array}$ & $\begin{array}{r}36.31 \\
\pm 4.15 \\
\end{array}$ & $\begin{array}{r}48.25 \\
\pm 3.65^{*} \\
\end{array}$ & $\begin{array}{r}38.12 \\
\pm 3.84^{\circ} \\
\end{array}$ \\
\hline & Total cholesterol (mg/g wet tissue) & $\begin{aligned} & 3.11 \\
& \pm 2.54 \\
&\end{aligned}$ & $\begin{array}{r}3.22 \\
\pm 4.15 \\
\end{array}$ & $\begin{array}{c}4.01 \\
\pm 2.35 \\
\end{array}$ & $\begin{array}{c}9.22 \\
\pm 1.15 * \\
\end{array}$ & $\begin{array}{c}4.32 \\
\pm 2.56^{\circ} \\
\end{array}$ \\
\hline & Triglycerides (mg/g wet tissue) & $\begin{array}{r}22.16 \\
\pm 5.45 \\
\end{array}$ & $\begin{array}{r}20.31 \\
\pm 3.21 \\
\end{array}$ & $\begin{array}{r}24.31 \\
\pm 3.25 \\
\end{array}$ & $\begin{array}{r}34.10 \\
\pm 2.45^{*} \\
\end{array}$ & $\begin{array}{r}27.22 \\
\pm 1.98^{\circ} \\
\end{array}$ \\
\hline & Phospholipid ( $\mu \mathrm{mol} / \mathrm{min} / \mathrm{g}$ dry tissue) & $\begin{array}{l}40.32 \\
\pm 2.01\end{array}$ & $\begin{array}{l}38.51 \\
\pm 2.35\end{array}$ & $\begin{array}{l}42.25 \\
\pm 1.26\end{array}$ & $\begin{array}{c}48.31 \\
\pm 2.78^{*}\end{array}$ & $\begin{array}{c}38.21 \\
\pm 2.35^{\circ}\end{array}$ \\
\hline
\end{tabular}

Results are presented as means \pm SE. $(\mathrm{n}=5)$.

- $\mathrm{P}<0.05$ compared to control (Group I).

$\mathrm{P}<0.05$ compared to group III.

${ }^{\circ} \mathrm{P}<0.05$ compared togroup IV. 
Table(3): Changes in lactic dehydrogenase ( $\mathrm{LDH})$, creatine kinase (CK), aspartate aminotransferase (AST) and alanine aminotransferase (ALT) enzymes activities in serum, liver and heart of control and treated groups.

\begin{tabular}{|c|c|c|c|c|c|c|}
\hline & $\begin{array}{c}\text { Groups } \rightarrow \\
\text { Parameters } \downarrow\end{array}$ & $\begin{array}{c}\text { Group } \\
\text { I }\end{array}$ & $\begin{array}{c}\text { Group } \\
\text { II }\end{array}$ & $\begin{array}{c}\text { Group } \\
\text { III }\end{array}$ & $\begin{array}{l}\text { Group } \\
\text { IV }\end{array}$ & $\begin{array}{c}\text { Group } \\
\mathrm{V}\end{array}$ \\
\hline \multirow{4}{*}{ 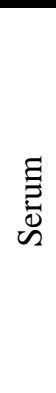 } & LDH (U/l) & $\begin{array}{l}385.31 \\
\pm 3.25\end{array}$ & $\begin{array}{l}380.11 \\
\pm 1.28\end{array}$ & $\begin{array}{l}390.21 \\
\pm 3.63\end{array}$ & $\begin{array}{c}450.10 \\
\pm 2.95 *\end{array}$ & $\begin{array}{l}401.21 \\
\pm 3.41^{\circ}\end{array}$ \\
\hline & $\mathrm{CK}(\mathrm{U} / \mathrm{l})$ & $\begin{array}{r}60.22 \\
\pm 3.32\end{array}$ & $\begin{array}{c}59.31 \\
\pm 1.25\end{array}$ & $\begin{array}{c}62.11 \\
\pm 4.25\end{array}$ & $\begin{array}{c}108.62 \\
\pm 3.25 *\end{array}$ & $\begin{array}{c}80.32 \\
\pm 2.32^{\circ}\end{array}$ \\
\hline & $\mathrm{AST}(\mathrm{U} / \mathrm{l})$ & $\begin{array}{r}24.13 \\
\pm 1.12\end{array}$ & $\begin{array}{r}23.15 \\
\pm 2.25\end{array}$ & $\begin{array}{l}26.11 \\
\pm 0.36\end{array}$ & $\begin{array}{c}31.31 \\
\pm 1.05 *\end{array}$ & $\begin{array}{c}25.22 \\
\pm 1.32^{\circ}\end{array}$ \\
\hline & ALT (U/l) & $\begin{array}{r}18.12 \\
\pm 2.25\end{array}$ & $\begin{array}{r}20.22 \\
\pm 1.45\end{array}$ & $\begin{array}{r}24.32 \\
\pm 2.05^{\circ}\end{array}$ & $\begin{array}{c}31.21 \\
\pm 1.98 *\end{array}$ & $\begin{array}{r}22.20 \\
\pm 2.14^{\circ}\end{array}$ \\
\hline \multirow{4}{*}{ 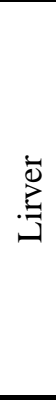 } & $\mathrm{LDH}(\mathrm{U} / \mathrm{g})$ & $\begin{array}{l}309.12 \\
\pm 3.25\end{array}$ & $\begin{array}{l}311.15 \\
\pm 5.25\end{array}$ & $\begin{array}{l}322.22 \\
\pm 4.25^{\circ}\end{array}$ & $\begin{array}{c}381.11 \\
\pm 3.25 \text { * }\end{array}$ & $\begin{array}{l}340.21 \\
\pm 2.35^{\circ}\end{array}$ \\
\hline & CK (U/g) & $\begin{array}{c}80.31 \\
\pm 2.15\end{array}$ & $\begin{array}{c}84.11 \\
\pm 3.25\end{array}$ & $\begin{array}{c}98.12 \\
\pm 2.36^{\circ}\end{array}$ & $\begin{array}{c}137.32 \\
\pm 3.63 *\end{array}$ & $\begin{array}{r}102.32 \\
\pm 4.11^{\circ}\end{array}$ \\
\hline & AST (U/g) & $\begin{array}{r}12.22 \\
\pm 2.21\end{array}$ & $\begin{array}{c}13.41 \\
\pm 3.25\end{array}$ & $\begin{array}{r}14.25 \\
\pm 2.35\end{array}$ & $\begin{array}{c}21.71 \\
\pm 2.25 *\end{array}$ & $\begin{array}{c}15.41 \\
\pm 1.54^{\circ}\end{array}$ \\
\hline & ALT (U/g) & $\begin{array}{c}8.31 \\
\pm 3.20\end{array}$ & $\begin{array}{c}8.01 \\
\pm 2.30\end{array}$ & $\begin{array}{c}9.21 \\
\pm 2.45\end{array}$ & $\begin{array}{c}16.31 \\
\pm 1.85 *\end{array}$ & $\begin{array}{c}9.22 \\
\pm 1.03^{\circ}\end{array}$ \\
\hline \multirow{4}{*}{ 营 } & $\mathrm{LDH}(\mathrm{U} / \mathrm{g})$ & $\begin{array}{l}411.22 \\
\pm 3.61\end{array}$ & $\begin{array}{l}409.31 \\
\pm 3.25\end{array}$ & $\begin{array}{l}422.14 \\
\pm 3.65^{\circ}\end{array}$ & $\begin{array}{c}480.32 \\
\pm 4.15 *\end{array}$ & $\begin{array}{l}412.25 \\
\pm 4.18^{\circ}\end{array}$ \\
\hline & CK (U/g) & $\begin{array}{l}111.41 \\
\pm 2.52\end{array}$ & $\begin{array}{l}109.25 \\
\pm 2.35\end{array}$ & $\begin{array}{l}122.14 \\
\pm 2.58^{\circ}\end{array}$ & $\begin{array}{c}298.23 \\
\pm 3.25 *\end{array}$ & $\begin{array}{r}196.23 \\
\pm 3.25^{\circ}\end{array}$ \\
\hline & AST (U/g) & $\begin{array}{l}17.81 \\
\pm 2.47\end{array}$ & $\begin{array}{r}17.91 \\
\pm 8.32\end{array}$ & $\begin{array}{l}18.31 \\
\pm 6.35\end{array}$ & $\begin{array}{r}27.25 \\
\pm 3.25\end{array}$ & $\begin{array}{r}18.31 \\
\pm 5.65\end{array}$ \\
\hline & ALT (U/g) & $\begin{array}{c}9.11 \\
\pm 3.21 \\
\end{array}$ & $\begin{array}{c}8.89 \\
\pm 2.36 \\
\end{array}$ & $\begin{array}{c}10.12 \\
\pm 3.54\end{array}$ & $\begin{array}{r}17.80 \\
\pm 3.17\end{array}$ & $\begin{array}{r}13.22 \\
\pm 2.51\end{array}$ \\
\hline
\end{tabular}

Results are presented as means \pm SE. $(n=5)$.

$\bullet \mathrm{P}<0.05$ compared to control (Group I).

*P $<0.05$ compared to group III.

${ }^{\circ} \mathrm{P}<0.05$ compared togroup IV. 
Table (4): Changes in serum calcium, potassium and magnesium concentrations, as well as calcium/magnesium ratio of control and treated groups.

\begin{tabular}{|c|c|c|c|c|c|c|}
\hline & $\begin{array}{c}\text { Groups } \rightarrow \\
\text { Parameters } \downarrow\end{array}$ & $\begin{array}{c}\text { Group } \\
\text { I }\end{array}$ & $\begin{array}{l}\text { Group } \\
\text { II }\end{array}$ & $\begin{array}{l}\text { Group } \\
\text { III }\end{array}$ & $\begin{array}{c}\text { Group } \\
\text { IV }\end{array}$ & $\begin{array}{c}\text { Group } \\
\mathrm{V}\end{array}$ \\
\hline \multirow{4}{*}{$\begin{array}{l}\Xi \\
\overbrace{0}^{0} \\
\end{array}$} & $\mathrm{Ca}(\mathrm{mg} / \mathrm{dl})$ & $\begin{array}{c}7.66 \\
\pm 1.02\end{array}$ & $\begin{array}{c}7.08 \\
\pm 0.64\end{array}$ & $\begin{array}{c}6.22 \\
\pm 0.23\end{array}$ & $\begin{array}{c}11.74 \\
\pm 1.03 *\end{array}$ & $\begin{array}{r}6.54 \\
\pm 0.87^{\circ}\end{array}$ \\
\hline & $\mathrm{K}(\mathrm{mmol} / \mathrm{l})$ & $\begin{array}{c}3.58 \\
\pm 2.25\end{array}$ & $\begin{array}{c}3.64 \\
\pm 1.02\end{array}$ & $\begin{array}{c}4.25 \\
\pm 1.25\end{array}$ & $\begin{array}{c}3.31 \\
\pm 1.32\end{array}$ & $\begin{array}{c}5.98 \\
\pm 1.36\end{array}$ \\
\hline & $\mathrm{Mg}(\mathrm{mg} / \mathrm{dl})$ & $\begin{array}{c}2.99 \\
\pm 1.20\end{array}$ & $\begin{array}{c}3.85 \\
\pm 1.23\end{array}$ & $\begin{array}{c}3.78 \\
\pm 2.10\end{array}$ & $\begin{array}{c}2.68 \\
\pm 1.02\end{array}$ & $\begin{array}{c}3.78 \\
\pm 1.32\end{array}$ \\
\hline & $\mathrm{Ca} / \mathrm{Mg}$ Ratio & $\begin{array}{c}2.56 \\
\pm 1.02\end{array}$ & $\begin{array}{c}1.84 \\
\pm 0.32\end{array}$ & $\begin{array}{c}1.64 \\
\pm 0.36\end{array}$ & $\begin{array}{c}4.38 \\
\pm 1.12\end{array}$ & $\begin{array}{c}1.74 \\
\pm 1.09\end{array}$ \\
\hline
\end{tabular}

Results are presented as means \pm SE. $(n=5)$.

$\cdot \mathrm{P}<0.05$ compared to control (Group I).

$* \mathrm{P}<0.05$ compared to group III.

${ }^{\circ} \mathrm{P}<0.05$ compared to group IV.

\section{Discussion}

Todate, intervention studies of disease prevention using vegetables, fruit, or both are rare. Consumption of a low-fat diet enriched with fruit and vegetables compared with a standard low-fat diet was associated with an apparent $40 \%$ reduction in cardiac events and a $45 \%$ reduction in mortality in 406 men with myocardial infarction. (Singh et al., 1993).

A diet rich in vegetables and fruit may provide protection against cardiovascular disease (Ness and powles, 1997). Serdula et al. (1996) showed that increased intake of fresh fruit and vegetables increased the level of physical activity. Higher Lycopene concentration in the adipose tissue tended to be most protective against myocardial infarction in human (Kohlmeier et al., 1997).

As presented in Table (1), body weigt gain in rats fed a diet enriched with $20 \%$ fried potato in deep frying oil for 8 weeks higher than those fed the control diet enriched with $20 \%$ fried potato in fresh

frying oil. The result agree with Huang et al. (1988) as well as Liu and Huang (1995). The obtained data may be due to hyperlipidemia and hypercholesterolemia. However, the treatment with tomato juice restored the body weight gain to the level of that of the corresponding control group.

Dietary manipulation, particulary of fats, result in marked changes in lipid profiles and lipoprotein composition (Adamopoulos et al., 1996) In the present study, it has been found that, total lipids, total cholesterol, triglycerides and phospholipids in addition lipoprotein pattern; especially LDL-cholesterol were significantly increased in rats fed deep fried potato in oxidized frying oil (Group IV) compared to those of the fried potato in fresh frying oil (Group III). However, HDL-cholesterol showed a significant decrease in the same animals (Table 2). These results are in agreement with those reported by Broekmans et al. (2003) who recorded higher plasma cholesterol, triglycerides and 
LDL-cholesterol levels in human fed deep fried potato. In addition Liu and Lee (1998) observed that plasma cholesterol concentration was highest in guinea pigs fed oxidized frying oil. Furthermore, Abdel Hamid et al. (1993) revealed hyperlipidemia and hypercholesterolemia in the liver of sheep fed on boiled Sun oil. These findings may be attributed to increase of synthesis of fatty acids in the liver or possibility of incidence of liver cholestosis (Zilva and Pannall, 1975). The elevation in the lipid fraction may be also due to appearance of different fractions of low molecular weight compounds from such oxidized oils due to heat oils for prolonged time. Some of these compounds are much toxic and accumulate in the deep fried food and can change the metabolism of lipids (Eder, 1999). Changes in lipoproteins composition, transport and/ or turnover taken into consideration by Steinberg (1979).

In the present work, our results showed therapeutic effect of oral intake of lycopene as tomato juice for treating the occurred hyperlipidemia due to dietary deep frying potato. This effect is manifested by the significant decrease in total lipids, total cholesterol, triglycerides and phospholipids as well as LDL-cholesterol and a marked elevation in HDL-cholesterol. This coincides with data previously observed in human by Maruyama et al. (2001) and Sesso et al. (2003). It could be contributed to the role of lycopene in protecting LDL or phospholipid in LDL from oxidation in addition to its role in inhibition of cholesterogenesis by inhibit hydroxymethylglutaryl coenzyme A (HMG-CoA) reductase activity and to upregulate LDL receptor activity in macrophages (Arab and Steck, 2000 and Heber and Qy, 2002) or may be due to its powerful antioxidant that has been shown to neutralize free radicals, especially those derived from oxygen, resulting in protection against chronic disease especially coronary heart disease (Agarwal and Rao, 2000).

As shown in table (3), there was a marked increase in heart energetic enzyme activity in group IV. An expected results which may reveal cellular damage in heart, liver and kidney by fried food thermally oxidized fat were detected by Alexander (1981). This damage may be due to undesirability of primary lipoxy radical under high temperature and formation of polymer compounds and carbonyls. Feeding rats on deep fried potato induced notable elevation in the serum, liver and cardiac activities of LDH, CK, AST and ALT. These results may be attributed to hyperlipidemia that leads to liver tissue injury. So when cell membrane get damage, these enzymes which are normally located in the cytosol leak in the blood streams thus manifesting damage affected liver and other tissues. These results were in accordance with Shyamala et al. (2003), who reported that both ALT and AST enzymes activities were increased in rats fed with high fat diet. Also, the observed increasing in LDH and CK activities may be attributed to a generalized increase in membrane permeability (Doran and Wilkinson 1975). Heart disease due to hyperlipidemia may play a role in these results, it has been reported that a significant elevation in LDH activity was detected in heart diseases (Lanter, 1975). Also, Elevated serum total cholesterol, LDL-cholesterol, and triacylglycerol concentrations, as well as reduction in HDL-cholesterol concentrations, are identified risk factors for coronary artery disease (Austin, 1991). Elevation of the above mentioned enzymes may be attributed to circulatory failure with shock and hypoxia or myocardial infarction (Julian et al., 2000).

Furthermore, the most interesting effect of lycopene was achieved by reduced the hyper activity of LDH, CK, AST and ALT in rat fed deep fried potato in oxidized frying oil accompanied by neutralization the electrolytes pattern by elevation of $\mathrm{K}$ and $\mathrm{Mg}$ and inhibition of $\mathrm{Ca}$ influx. This effect may be attributed to alterations of the plasma membranes of the hepatocytes.

Regarding to the estimated electrolytes, the data showed disturbance in serum $\mathrm{Ca}, \mathrm{K}$ and $\mathrm{Mg}$ as hypercalcemia, hypokalemia and hypomagnesemia, these indicating heart disorders in the rat fed deep fried potato. Consequently, the lowering in potassium and magnesium could be 
attributed to the muscular weakness, hypotonia and cardiac arrhythmias (Mayne, 1994). Another possible interpretation for the decrease in $\mathrm{K}$ and $\mathrm{Mg}$ ions in rats fed on deep fried potato could be related to elevation in free fatty acids (FFAs) which may be caused disturbance of muscular function as Flink et al. (1979) reported that increases in the circulating FFAs levels can reduce the divalent cation.

Moreover, an undesirable rise in the ratio of serum calcium/magnesium was recorded in deep fried potato fed rats where the ratio between calcium to magnesium is very important in dealing with the causes and prevention of a number of disorders including myocardial infraction or arrhythmia, atherosclerosis, hypertension, urolithiasis, and infant-death syndrome. The observed elevation of the $\mathrm{Ca} / \mathrm{Mg}$ ratio may be due to the elevation of calcium and inhibition of magnesium in rats fed deep fried potato. In all cases, a lower calcium/ magnesium ratio or a higher magnesium/ calcium ratio is desirable (Karppanen et al., 1978 and Esashi, 1992). While, the neutralization of the ions levels were achieved by clear improvement in the observed imbalances in these electrolytes when administration of lycopene to rats fed deep fried potato in frying oil. The obtained results may be attributed to alterations of the physiological activity of the heart muscle and cell membrane permeability, an explanation, which need further investigation.

The therapeutic effect of lycopene recorded in the present investigation may be due to lycopene's antioxidant activity (Copper et al., 1999)

In conclusion: The oral intake of lycopene rich tomato juice might be beneficial for ameliorating the cardiac disorders arising sometimes from dietary oxidizing fat in deep fried food. So eating a balanced diet, which plenty of fruits and vegetables is important against the noteworthy effect of the update take away highly fat foods.

\section{References}

1. AbdelHamid, A. M.; Gabr, A.A. and ElShinaway, M. M. (1993): "Effect of partially substituting concentrate feed mixture by either fresh of waste oil in sheep diets". Arch. Tierernahr; 44:187-194.

2. Adamopoulos, P.N.; Papamichael, C.M.; Zampelas, A. and Moulopoulos, S. D. (1996): "Cholesterol and unsaturated fat diets influence lipid and glucose concentrations in rats". Biochem. Physical., 113: 659-663.

3. Agarwal, S.and Rao,AV.(2000): “Tomato lycopene and its role in human health and chronic diseases". Canadian Med. Assoc. J., 163 19: 739-744.

4. Alexander, JC. (1981): "Chemical and biological properties related to toxicity of heated fats". J. Toxicol. Environ. Health, 7: 125- 138.

5. Arab, L. and Steck, S. (2000): "Lycopene and cardiovascular disease". Am. J. Clin. Nutr., 71: 1691S-1695S.

6. Austin, MA. (1991): "Plasma triglyceride and coronary heart disease". Arterioscler. Thromb., 11:2-14.

7. Baginiski, E. B.; Epsteine, E. and Zak, B. (1972): "Determination of phospholipids in plasma”. Ann. Clin. Lab. Sci., 2 : 255-260.

8. Banerjee, S. K. and Maulik, S. K. (2002): "Effect of garlic on cardiovascular disorders". J. Nutr., 1:4-36.

9. Battino, M.; Quiles, J.L.; Huertas, J. R.; Ramirez, M.C.; Tortosa, M., Cassinello, M. ; Manas, L.; Frias, M. and Mataix, J. (2002): "Feeding fried oil changes antioxidant and fatty acid pattern of rat and affects rat liver mitochondrial respiratory chain components". Bioenerg. Biomembr. 34: 127-134.

10. Bramley, PM. (2000): "Is lycopene beneficial to human health?" Phytochem.; 54: 233-236.

11. Broekmans, W. M.; Klopping-Ketelaars, I. A.; Weststrate, J,A.; Tijburg, L. B.; Poppel, G. V.; Vink, A. A.; Berendschot, T. T.; Bots, M.L.; Castenmiller, W. A. and Kardinaal, A. F. (2003): "Decreased carotenoid concentrations due to dietary sucrose polyesters do not affect possible markers of disease risk in humans". J. Nutr., 133:720-726.

12. Clinton, SK. (1998): "Lycopene: chemistry, biology, and implications for human health and disease". Nutr Rev.; 56:35-51.

13. Copper, D. A.; Eldridge, A. L. and Peters, J. C. (1999): "Dietary carotenoids and certain cancers, heart disease, and agerelated macular degeneration: a review of recent research". Nutr. Rev. 57:201-214. 
14. Doran, G. R. and Wilkinson, J. H. (1975): "The origin of the elevated activities of creatine kinase and other enzymes in the sera of patients with myxoedema. Clin. Chem. Acta., 62: 203.

15. Eder, K. (1999): The effects of a dietary oxidized oil on lipid metabolism in rats". Lipids, 34: 717-725.

16. Ernst, J. and Schaefer, I. (2002): "Lipoproteins, nutrition and heart disease". Am. J. of Clin. Nutr., 75: 191-212.

17. Esashi T. (1992): "Calcium and magnesium”. Rinsho Eiyo (Clin. Nutr.) 81: 288-294.

18. Flink, E. B.; Shane, S. R. and Scobbo, R.R. (1979): "Relationship of free fatty acids and magnesium in ethanol withdrawall in dogs". Metabolism 28: 858-865.

19. Giovannucci, E. J. (1999): "Tomatoes, tomato-based products, lycopene and cancer: review of the epidemiologic literature". J. of National Cancer Institute 91: 317-331.

20. He, M.; Openo, K.; Cullough, M. M. and Jones, D.P. (2004): "Total equivalent of reactive chemicals in 142 human food items is highly variable within and between major food groups". J. Nutr., 134:1114-1119.

21. Heber, D. and Qy, LU. (2002): “Overview of mechanisms of action of lycopene".Exp. Biol. Med. (Maywood) 227: 920-923.

22. Huang, C. J.; Cheung, N. S.and Lu, V. R. (1988): "Effects of delteriorated frying oil and dietary protein levels on liver microsomal enzymes in rats". J. Am. Oil Chem. Soc., 65: 1796-1803.

23. Julian, D.; Cowan, J. and McLenachan, J. (2000): "Heart failure" In: Cardiology International Edition, Harcourt Publishers Ltd. North Yorkshire, China. PP:129-153.

24. Karppanen, H.; Pennanen, R. and Passinen, L. (1978): "Minerals, coronary heart disease and sudden coronary death".Adv.Cardiol.,25:9-24.

Kohlmeier, L.; Kark, JD.; GomezGracia, E.; Martin, BC.; Steck, SE.; Kardinaal, AMF.; Ringstad J.; Thamm M.; Masaev V.; Riemersma R.; MartinMoreno JM.; Huttunen JK and Kok F. (1997): "Lycopene and myocardial infraction risk in the Euramic study". Am. J. Epidemiol., 146: 618-626.

25. Lampe, J. W. (1999): "Health effects of vegetables and fruit: assessing mechanisms of action in human experimental studies". Am. J. Clin. Nutr., 70: 475S-490S.
26. Lanter, A. B. (1975): "Clinical biochemistry". 7th ed., Saunder. W. B. company, Philadelphia, London, Toron.

27. Liu, C.; Lian, F.; Smith, D. E.;Russell, R. M.and Wang, X. D. (2003): "Lycopene supplementation inhibits lung seqamous metaphasia and induces apoptosis via upregulating insulin-like growth factorbinding protein 3 in cigarette smokeexposed ferrets". Cancer Research, 63: 3138-3144.

28. Liu, J. F, and Huang, C. J. (1995): "Tissue a-tocopherol retention in male rats is compromised by feeding diets containing oxidized frying oils". J. Nutr., 125: 30713080.

29. Liu, JF. and Lee, YW. (1998): "Vitamine C supplementation restores the impaired vitamin $E$ status of guinea pigs fed oxidized frying oil" . J. of Nutr. 128: 116-122.

30. Maruyama, C.; Imamura, K.; Oshima, S.; Suzukawa, M.; Egami, S.; Tonomoto, M.; Baba, N.; Harada, M.; Ayaori, M.; Inakuma, T.and Ishikawa, T.(2001): "Effects of tomato juice consumption on plasma and lipoprotein carotenoid concentrations and the susceptibility of low density lipoprotein to oxidative modification". J. Nutr. Sci. Vitaminol., 47: 213-221.

31. Mayne, P. (1994): "Plasma enzymes in diagnosis". In: Clinical Chemistry in Diagnosis and Treatment. $6^{\text {th }}$ edition, E. Arnold, England. PP.300-309.

32. Micozzi, MS; Brown, ED.; Edwards, BK.; Bieri, JG.; Taylor, PR.; Khachik, F.; Beecher, GR. And Smith, JC. (1992): "Plasma carotenoid response to chronic intake of selected foods and beta-carotene suplements in men" Am. J. Clin. Nutr., 55: 1120-1125.

33. Ness AR, Powles JW. (1997): "Fruit and vegetables, and cardiovascular disease: a review". Int J Epidemiol ; 26:1-13.

34. Otero, O. (1997): "Are trans-fatty acids a serious risk for disease". Am J Clin Nutr., 66(S):1018S-1019S.

35. Paetau, I; Rao, D.; Wiley, E. R.; Drown, E.D. and Clevidence, B. A. (1999): "Carotenoids in human buccal mucosa cells after $4 \mathrm{wk}$ of supplementation with tomato juice or lycopene supplement". Ame. J. of Clin. Nutr., 70: 490-494.

36. Seifried, H. E., McDonald, S. S., Anderson, D. E., Greenwald, P.and Milner, J. A. (2003): "The Antioxidant Conundrum in Cancer". Cancer Res 63: 4295-4298. 
37. Serdula MK.; Byers T.; Mokdad AH.; Simoes E.; Mendlein JM.and Coates RJ. (1996): "The association between fruit and vegetable intake and chronic disease risk factors". Epidemiology, 7:161-165.

38. Sesso, H.D.; Liu, S.; Gaziano, J.M. and Buring, J. E. (2003): "Dietary Lycopene, Tomato-Based Food Products and Cardiovascular Disease in women". J. Nutr., 133: 2336-2341.

39. Shyamala, M.P.; Venukumar, M.R. and Latha, M.S. (2003): “Antioxidant potential of the Syzygium aromaticum(gaerln) Linn. (cloves) in rats fed with high fat diet". Indian J of Pharm.; 35: 99-103.

40. Singh, RB; Niaz MA; Gosh S.; and Rastogi SS.(1993): "Effect on mortality and reinfarction of adding fruits and vegetables to a prudent diet in the Indian experiment of infarct survival (IEIS)". J Am. Coll Nutr., 12:255-261.
41. Sokal, R. R. and Rahif, F. J. (1981): "The Principles and Practice of Statistics in Biological Research" 2nd. Ed. Freeman, W. H. Compony, San Francisco.

42. Steinberg, D. (1979). "Origin turnover and fate of plasma low-density lipoprotein". In: Progress in biochemical pharmacology (Eisenberg, S. ed), 15: 166-199 Karger, Basel, Switzerland.

43. Steinmetz KA and Potter JD (1996): "Vegetables, fruit, and cancer prevention: a review". J Am. Diet Assoc ,96:1027-1039.

44. Zettner, A. and Seligson, D. (1964): Quited from Hawk's physiological chemistry 14, th Edition, P. 1008 and 1136. Published by Tata Mc Graw-Hill Publishing Compony LTD. New Delhi Clin. Chem., 10:869.

45. Zilva, J. F. and Pannall, P. R. (1975): "Clinical chemistry in diagnosis and treatment". $2^{\text {nd }}$ Edition, Ll oyd-Luke (Medical books) LTD, London. p. 294-300. 


\section{التأثير العلاجي لعصير الطماطم الغنى بالليكوبين على الاختلال القلبي في جرذان

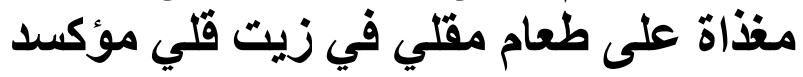

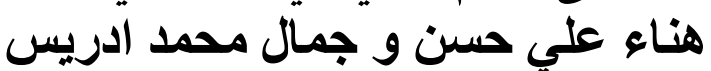

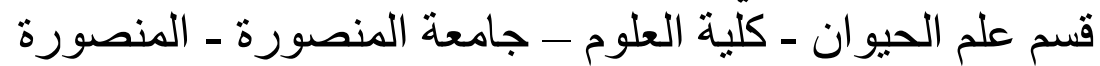

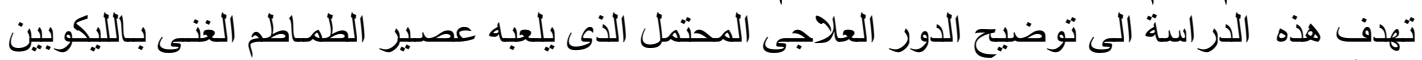

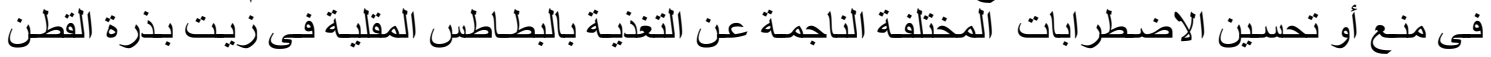

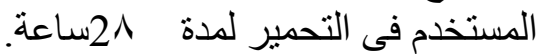

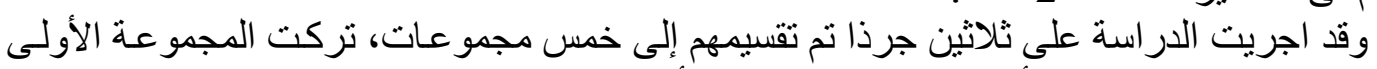

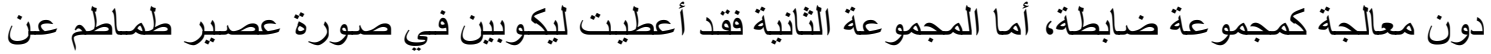

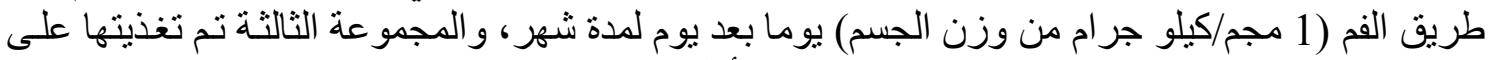

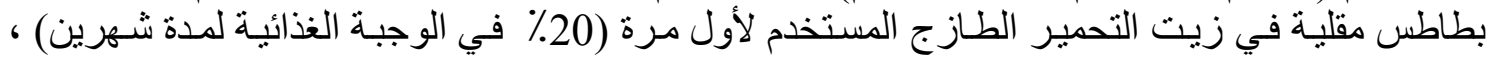

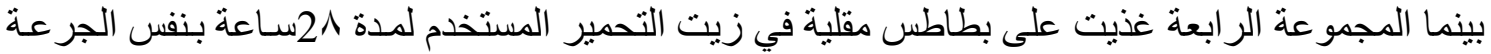

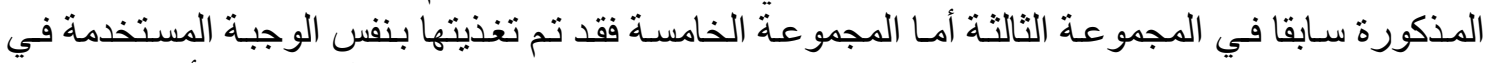

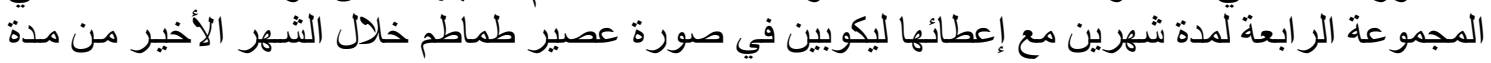

التغذية.

هذا وقد تم تعين بعض المعايير الفسيولوجية لأيض الدهون و الدهون البروتينية مثنل الدهون الكلية،

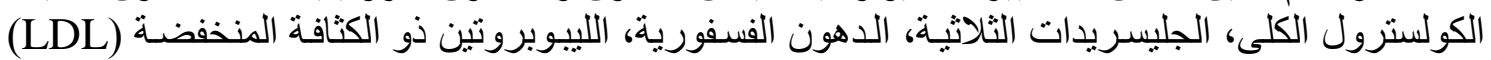

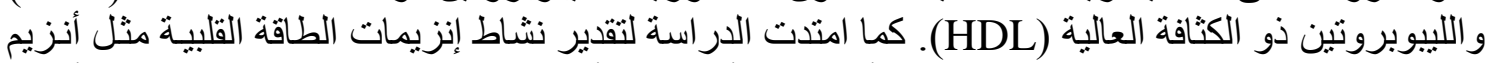

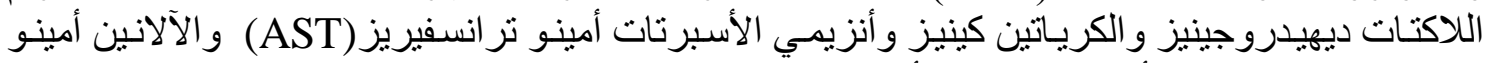

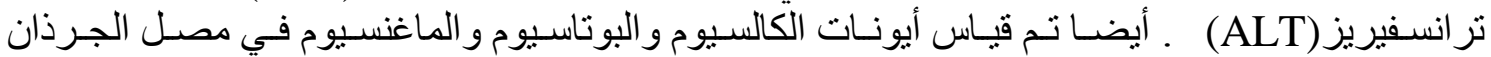

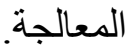

وقد أ سفرت النتائج عن أن التغذيـة على البطاطس المقلية في زيت التحمير الطـازج المستخدم لأول

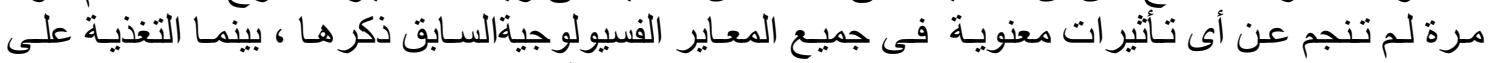

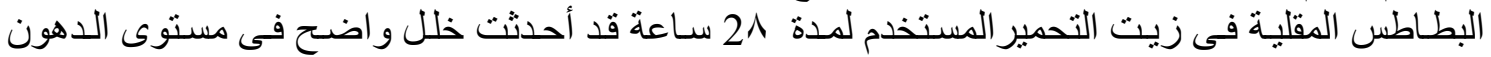

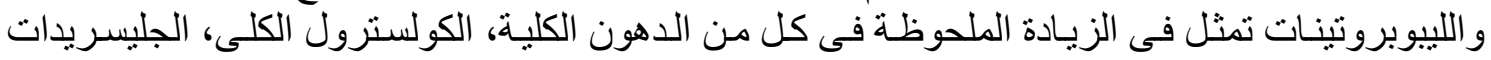

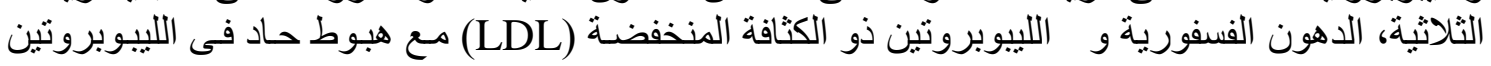

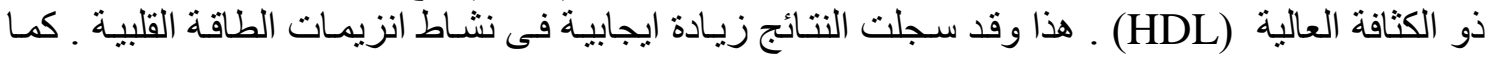

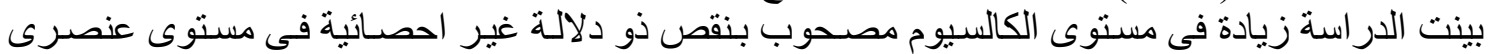

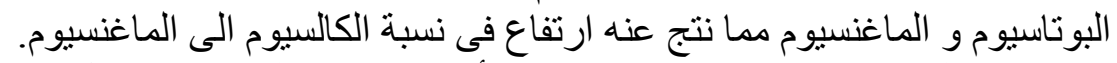

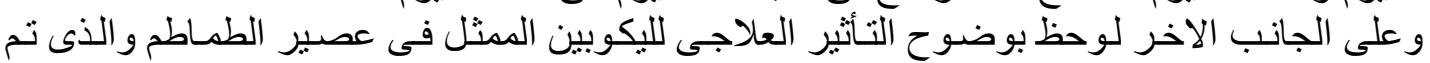

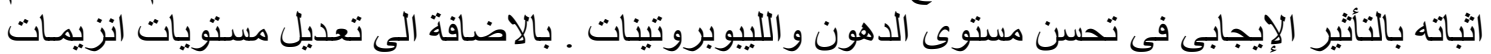

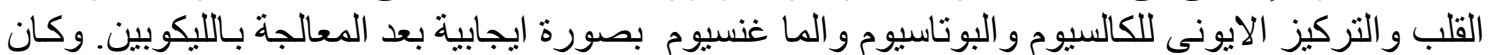

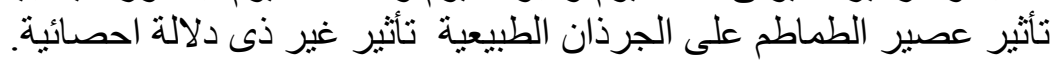

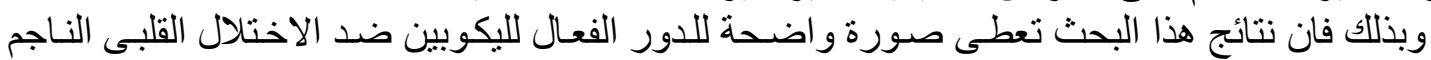

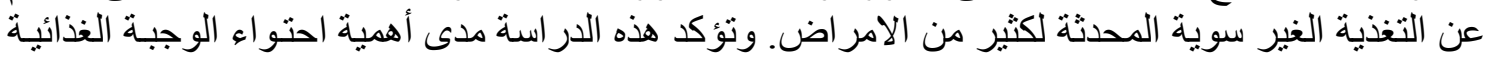

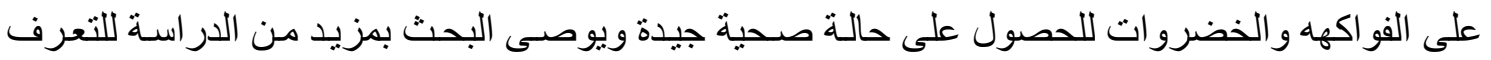

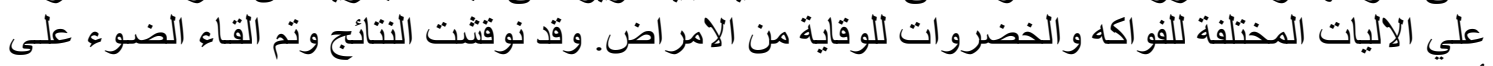

